\title{
Gluteus maximus island flap for the repair of sacral pressure sores
}

\author{
Aditya Aggarwal, SS Sangwan, RC Siwach and KM Batra \\ Postgraduate Department of Orthopaedic Surgery, Paraplegia, Physical Medicine and Rehabilitation, Medical \\ College \& Hospital, Rohtak 124 001, India
}

\begin{abstract}
Surgical management of decubitus ulcers in spinal cord injured patients (SCI) has been considerably improved by the application of muscle, myocutaneous and fasciocutaneous flaps. The goal of the present study was to do a critical analysis of the use of a gluteus maximus island flap for sacral pressure sores in paralysed as well as nonparalysed patients. In a prospective study, 34 patients with sacral pressure sores from grade V to VII were treated by gluteus maximus myocutaneous island flaps. Follow up ranged from 1.8 years to 6.2 years. Results were evaluated according to criteria based on (i) extent of wound dehiscence (ii) flap necrosis (iii) recurrence. Final results were excellent to good in 30 cases $(88.3 \%)$. Poor results occurred in two patients $(5.8 \%)$ and recurrence in one $(2.9 \%)$ due to a major flap necrosis. Postoperative infection and wound dehiscence occurred in two cases each. No systemic complications occurred except for one patient who died from uraemia. The rehabilitation of these patients was improved. The postoperative duration of stay in hospital was from 18 to 32 days (mean: 22.5 days). The majority of the patients were quite pleased with the operation.
\end{abstract}

Keywords: pressure sores; surgery; myocutaneous flap; gluteus maximus flap

\section{Introduction}

Pressure sores are, unfortunately, a common complication of prolonged confinement of paralysed people including paraplegia, tetraplegia and hemiplegia. Because of their occurrence, rehabilitative measures may be postponed and morbidity is often severe and prolonged so that if not controlled, infection develops and death may ensue. ${ }^{1}$

Conservative treatment is not only time consuming and frustrating but also the scar formed is very thin and adherent to the underlying bone and may give way from quite trivial trauma. In a developing country such as India, most of these patients are referred to the hospital at a late stage after the initial trauma. Surgical treatment provides the best choice for early and long lasting cure.

Various surgical methods including split skin graft, multiple local flaps ${ }^{2}$ and myocutaneous $(\mathrm{mc})$ flaps $^{3,4}$ have been described. Maruyama and co-workers ${ }^{5}$ used gluteus maximus island mc flap without any recurrence or complication. Of all surgical modalities, myocutaneous flaps provide the best results.

Correspondence: Dr A Aggarwal, F-98, Kamla Nagar, Agra 282005 India.
The purpose of this paper is to describe our experience in the management of these patients by a gluteus maximus island myocutaneous flap.

\section{Material and methods}

The study was conducted prospectively from 1986 to 1992 on 34 patients who were admitted to the Paraplegia Centre of Medical College \& Hospital Rohtak, India.

Each had a full clinical examination, ${ }^{6}$ urine laboratory study, bacteriological study of the ulcers, and $\mathrm{X}$ ray studies.

Pressure sores were graded according to the clinical stages described by Campbell. ${ }^{7}$ Repeated debridement of the sores was done, a myocutaneous flap operation was carried out; then when there was healthy granulation tissue, Sacral decubitus ulcers in grades V to VII were treated by gluteus maximus island flaps.

About $70 \%$ patients developed pressure sores within a month after the spinal cord injury. $70 \%$ of these patients had a solitary pressure sore and 30\% multiple sores. Duration of pressure sores at the time of operation ranged from 20 days to 16 months (mean: 3.2 months). Dimensions of pressure sores were from 
$5.5 \times 5 \mathrm{~cm}$ to $13.5 \times 10 \mathrm{~cm}$. Bilateral gluteus maximus musculo-cutaneous flaps were done in 14 patients and unilateral in 20

\section{Preoperative preparation}

Patient was taught to practise lying down in a prone position. A high protein low residue diet was given. Bowel wash out done two days before operation. An indwelling Foley's catheter (no. 18) was inserted to avoid soakage of dressings. Preoperative planning and outlining of flap was done on the day prior to operation. Areas of scarring which might interfere with the proposed blood supply of the flap were excluded. The skin was examined for mobility, laxity and lines of minimal tension which facilitated transposition of the flap.

\section{Anaesthesia}

In the 30 patients with complete sensory loss due to paraplegia or tetraplegia, no anaesthesia was given. Only intravenous diazepam (10 $\mathrm{mg})$ was used to sedate the patient. In the four patients who had had tuberculous meningitis, a spinal anaesthesia was used.

\section{Applied anatomy of gluteus maximus island myocutaneous flap}

The gluteus maximus muscle arises from the external surface of the ilium behind the posterior gluteal line, the posterior surface of sacrum and coccyx and the sacrotuberous ligament. It is inserted into the gluteal tuberosity of the femur and the iliotibial tract. ${ }^{8}$ Vascular supply is from the superior and inferior gluteal arteries. The pattern of the circulation is type III having two dominant pedicles, being each $3 \mathrm{~cm}$ long and about $2.5 \mathrm{~mm}$ in diameter. The musculocutaneous perforators are distributed evenly over the

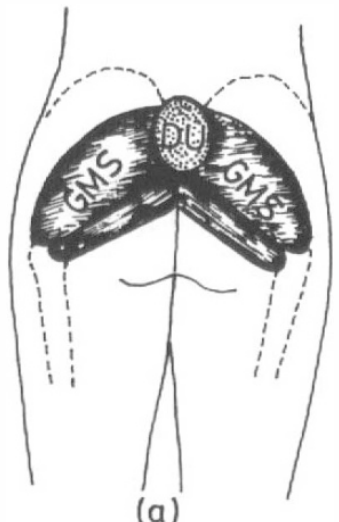

(a)

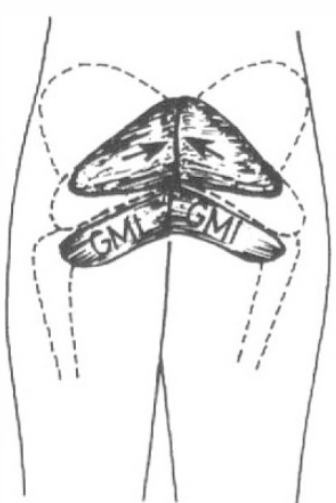

(b)

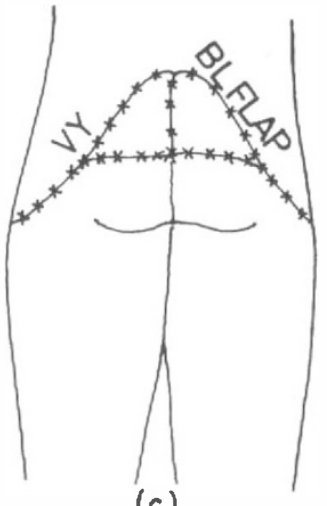

(c)
Figure 1 A schematic illustration of the gluteus maximus island flap based on its superior portion to treat a sacral decubitus ulcer. (a) Design of bilateral skin island on the superior portion of the gluteus maximus muscle. (b) Transposition of a bilateral island musculo-cutaneous flap to cover the ulcer with the inferior portion of gluteus maximus (GM) in place. (c) Primary closure of bilateral (BL) flap in a VY manner

Table 1 Scoring for evaluation of results

\begin{tabular}{|c|c|c|c|}
\hline Wound dehiscence & Flap necrosis & Recurrence & Scoring points \\
\hline No dehiscence & None & $\begin{array}{c}\text { None after } 6 \\
\text { months }\end{array}$ & 4 \\
\hline $\begin{array}{l}\text { Minor not requiring } \\
\text { suturing }\end{array}$ & $\begin{array}{c}\text { Minor not requiring } \\
\text { surgery }\end{array}$ & $\begin{array}{l}\text { Occurs between } \\
3-6 \text { months }\end{array}$ & 3 \\
\hline $\begin{array}{l}\text { Requiring secondary } \\
\text { suturing }\end{array}$ & $\begin{array}{c}\text { Requiring closure } \\
\text { of defect }\end{array}$ & $\begin{array}{l}\text { Occurs between } \\
11 / 2-3 \text { months }\end{array}$ & 2 \\
\hline Requiring skin graft & $\begin{array}{l}\text { Major; use of some } \\
\text { other flap necessary }\end{array}$ & $\begin{array}{l}\text { Within } 11 / 2 \text { months } \\
\text { of operation }\end{array}$ & 1 \\
\hline
\end{tabular}

Total score calculated and results labelled as:

\begin{tabular}{lc}
\hline Result & Total score \\
\hline Excellent & $>10$ \\
Good & $7-9$ \\
Fair & $4-6$ \\
Poor & 3 or less \\
\hline
\end{tabular}


muscle, and measure between $0.5 \mathrm{~mm}$ to $1 \mathrm{~mm}$ in diameter. $^{8}$

The skin territory of gluteus maximus measures approximately $24 \times 24 \mathrm{~cm}$ and includes the skin overlying the muscle and $2-3 \mathrm{~cm}$ beyond it. This muscle is a powerful extensor of the hip and stabilizer of the pelvis acting reciprocally with the tensor fascia lata. Thus the flap is based only on superior half of this muscle. 8

\section{Operative technique}

Patient prone. Excision of the abnormal skin, scar tissue and bursa. Sacral bony prominences excised. A triangular island flap of adequate size designed by

Table 2 Study group characteristics

\begin{tabular}{lc}
\hline Age at time of injury & No. of cases \\
\hline $10-19$ years & 2 \\
$20-29$ years & 12 \\
$30-39$ years & 11 \\
$40-49$ years & 6 \\
$50-59$ years & 3 \\
Sex & 30 \\
Males & 4 \\
Females & \\
Grading of pressure sores operated & 25 \\
V & 7 \\
VI & 2 \\
VII & \\
Duration between occurence and operation & 8 \\
$20-30$ days & 13 \\
$1-3$ months & 4 \\
$3-6$ months & 4 \\
$6-9$ months & 3 \\
$9-12$ months & 2 \\
$12-16$ months & \\
\hline
\end{tabular}

marking the skin with methylene blue overlying the superior half of the gluteus maximus muscle. Incision made through skin, subcutaneous tissue and the superior half of the gluteus maximus muscle, and a flap raised after detaching the muscle from its origin and insertion. Superior gluteal vessels carefully preserved. The composite musculo-cutaneous island flap shifted medially to cover the defect, and wound was closed in a V-Y manner. Two negative suction drains (no. 14) used to drain the wound (Figure 1).

For bilateral flaps, gluteus maximus island musculocutaneous flaps were raised on both sides and were stitched to each other after shifting medially to cover the sacral sore. The donor defect was covered by suturing both the flaps in a V-Y manner as for a unilateral flap. Two suction drains were put on each side (Figure 1).

\section{Postoperative care}

Low residue diet. Kept in a prone or lateral position. Periodic turning in bed was started immediately. Negative suction was continued until the collection of fluid stopped i.e. about 2-3 weeks postoperatively.

Patients were followed up initially monthly for 3 months, every 3 months for a year and then half yearly.

Table 4 Final results

\begin{tabular}{|c|c|c|c|}
\hline Result & $\begin{array}{c}\text { Bilateral } \\
(14)\end{array}$ & $\begin{array}{c}\text { Unilateral } \\
(20)\end{array}$ & $\begin{array}{l}\text { Total } \\
(34)\end{array}$ \\
\hline Excellent & 10 & 15 & 25 \\
\hline Good & 2 & 3 & 5 \\
\hline Fair & 1 & 1 & 2 \\
\hline Poor & 1 & 1 & 2 \\
\hline
\end{tabular}

Table 3 Postoperative complications and their management

\begin{tabular}{|c|c|c|}
\hline Complication & No of cases & Management \\
\hline Haematoma & 2 & $\begin{array}{l}\text { Drained after early removal of stitches } \\
\text { successfully }\end{array}$ \\
\hline $\begin{array}{l}\text { Drain blockage } \\
\text { or failure }\end{array}$ & 2 & $\begin{array}{l}\text { Drain removed. Haematoma formed was } \\
\text { drained by removing some sutures }\end{array}$ \\
\hline Seroma & 1 & Managed by repeated aspirations \\
\hline \multicolumn{3}{|l|}{ Infection } \\
\hline $\begin{array}{l}\text { i) Flap donor site } \\
\text { grafting }\end{array}$ & 1 & Antibiotics after $\mathrm{C} / \mathrm{S}$ followed by skin \\
\hline $\begin{array}{l}\text { ii) Flap recipient site } \\
\text { (Abscess formation) }\end{array}$ & 2 & $\begin{array}{c}\text { Drained by incision along suture line and } \\
\text { appropriate antibiotic }\end{array}$ \\
\hline Wound dehiscence & 2 & Secondary suturing \\
\hline \multicolumn{3}{|l|}{ Flap necrosis } \\
\hline major & 1 & Patient died of uraemia \\
\hline minor & 1 & Secondary suturing \\
\hline Recurrence & 1 & $\begin{array}{c}\text { Proper positioning and periodic turning of } \\
\text { patient in bed }\end{array}$ \\
\hline $\begin{array}{l}\text { Occurence of sores at } \\
\text { other sites }\end{array}$ & 2 & $\begin{array}{l}\text { Proper positioning and periodic turning of } \\
\text { patient in bed }\end{array}$ \\
\hline
\end{tabular}




\section{Results}

Postoperative local complications and their management are presented in Table 3. There were no systemic complications. Postoperative duration of stay in our hospital until discharge ranged from 18 days to 32 days (mean: 22.5 days). Follow up ranged from 1.8 years to 6.2 years (mean: 4.1 years).

The final results were excellent to good in 12 out of $14(85.7 \%)$ patients with bilateral operations, and 18 out of $20(90.0 \%)$ patients who required a unilateral gluteus maximus flap (overall result: $88.3 \%$ ) as is recorded in Table 4. Poor results were seen in two patients $(5.8 \%)$. The majority of the patients were pleased with their operating treatment.

\section{Discussion}

Management of pressure sores in SCI patients has been a perplexing problem. With conservative treatment, the bed occupancy time is greatly increased, thus leading to overall social and economic loss. ${ }^{9}$

Conway and Griffin ${ }^{10}$ were one of the first to describe the use of muscle flaps for pressure sores. The concept of myocutaneous flaps for these was introduced by Ger, ${ }^{3}$ who later in 1976 described the use of the gluteus maximus, rectus femoris and sartorius muscles for the treatment of sacral, ischial and trochanteric sores. ${ }^{11}$

In our study out of 34 patients, 24 were tetraplegic, six paraplegic and four had no neurological deficit.

Pressure sores occur over bony prominences because of prolonged continuous pressure. ${ }^{12,13}$ Thus ostectomy of the underlying bony prominence of the sacrum has been an important step in our management of these ulcers. This was done to distribute the pressure uniformly over a larger surface area, thus preventing the recurrence of sores. It also helped in the eradication of infection. The importance of ostectomy has been well documented in different studies. ${ }^{14,15}$

For sacral sores of less than $6 \mathrm{~cm}$ in diameter, a unilateral gluteus maximus island flap was used. Sores of more than $6 \mathrm{~cm}$ in diameter were covered with bilateral gluteus maximus musculo-cutaneous flaps because the vascular pedicle of the muscle allows a medial slide of only about $6 \mathrm{~cm}$.

Careful dissection, complete haemostasis and the use of two negative suction drains in each flap for about 2-3 weeks helped in reducing the complications incidence of postoperative infection, and of wound dehiscence due to haematoma or seroma formation. In our study, haematoma and seroma formation were seen in only two cases and in one case respectively. Postoperative infection and wound dehiscence occurred in two patients each.

In the study by Hill et l $^{16}$ on 17 paraplegic and three non paraplegic patients treated by a transverse back flap, major flap necrosis occurred in two cases $(10 \%)$ and minor necrosis in two cases $(10 \%)$. There was recurrence in four patients cases $(20 \%)$. Ger and Levine $^{11}$ in their excellent review of 40 muscle transposition procedures for primarily sacral (20) and trochanteric (17) ulcers, used the gluteus maximus in 23 patients cases and the rectus femoris in 10. The follow-up was poor and recurrent ulceration was attributed to the poor general health of the patients and the poor quality of aftercare.

In our study, excellent to good results were observed in 30 cases $(88.3 \%)$. Recurrence due to major flap necrosis in one case $(2.9 \%)$ was related to the general debilitating state of the patient. The poor results in two patients (including one with a major flap necrosis) were attributed to the poor quality of postoperative care and the general poor health of the patient. The advantage of the gluteus maximus island musculo-cutaneous flap is that it provides good soft tissue padding with thick muscle. There is no need for a split thickness skin graft. The surgical treatment of pressure ulcers by a myocutaneous flap helped in the general condition of the patient. The rehabilitation of the SCI patients could be started early, and the bed occupancy was reduced as was evidenced by the short postoperative stay of the patient in hospital (mean: 22.5 days).

\section{Conclusions}

A proximally based gluteus maximus island musculocutaneous flap is a very safe and reliable flap for the repair of sacral decubitus ulcers. No split skin grafting is needed. For a sacral ulcer of more than $6 \mathrm{~cm}$ in diameter, bilateral flaps should be done.

Important measures to prevent flap necrosis and recurrence are excision of underlying prominences, and the use of two negative suction drains. Continued proper measures to prevent any recurrence of pressure sores are absolutely essential.

\section{References}

1 Campbell RM, Delgado JP. Pressure Sore. In: Converse JM (ed). Reconstructive Plastic Surgery. WB Saunders, Philadelphia: 1977, pp 3763-3799.

2 Croce EJ, Schullinger RN, Schearer TP. The operative treatment of decubitus ulcers. Ann Surg 1946; 123: $53-59$.

3 Ger R. The surgical management of decubitus ulcers by musculocutaneous transposition. Surg 1971; 69: 106.

4 Minami RT, Mills R, Pardoe R. Gluteus maximus musculocutaneous flaps for repair of pressure sores. Plast Reconstr Surg 1977; 60: $242-252$

5 Maruyama Y et al. A gluteus maximus island flap for the repair of a sacral decubitus ulcer. Br J Plast Surg 1980; 33: 150-155.

6 Frankel HL et al. The value of postural reduction in the initial management of closed injuries of the spine with paraplegia and tetraplegia. Paraplegia 1969; 7: 179-192.

7 Campbell RM. The surgical management of pressure sores. Surg Clin North Am 1959; 39: 509-530.

8 Mathes SJ, Nahai F. Clinical applications for muscle and musculocutaneous flaps. CV Mosby Co, St Louis, Toronto, London, 1982, pp 12-465. 
9 Peterson NC, Bittman S. Epidemiology of pressure sores. Scand J Plast Reconstr Surg 1971; 5: 62-66.

10 Conway H, Griffin BH. Plastic surgery for closure of decubitus ulcers in patients with paraplegia. Am J Surg 1956; 91: 946-975.

11 Ger R, Levine SA. The management of decubitus ulcers by muscle transposition. Plast Reconstr Surg 1976; 58: 419.

12 Kosiak M. Etiology and pathology of ischaemic ulcers. Arch Phys Med Rehabil 1959; 40: 62-69.

13 Lindan O. Etiology of decubitus ulcers. An experimental study. Arch Phys Med Rehabil 1961; 42: 774-783.
14 Kostrubala JC, Greeley PM. The problem of decubitus ulcers in paraplegics. Plast Reconstr Surg 1947; 2: 403-412.

15 Blocksma R, Kostrubala JC, Greeley PM. The surgical repair of decubitus ulcers in paraplegics. Plast Reconstr Surg 1949; 4: $123-131$.

16 Hill L, Brown RG, Jurkiewicz MG. The transverse lumbosacral back flap. Plast Reconstr Surg 1978; 62: 177-184. 